\title{
USING THREONINE, CANTHAXANTHIN AND SODIUM SULPHATE, TO IMPROVE SECOND PRODUCTION CYCLE PERFORMANCE OF AGED HENS DURING SUMMER SEASON
}

\author{
Youssef, S.F.; Ali, M. N; Hoda E. El-Gabry and Abdelatif, H. A. \\ Anim. Prod. Res. Inst., Agric. Res. Center, Dokki, Giza, Egypt.
}

Corresponding author: Youssef, S.F. Email: sabbah.farouk@arc.sci.eg

Received: 09/08/2020 Accepted: 02 /09/2020

\begin{abstract}
This study testified the hypothesis that L threonine (Thr) and canthaxanthin $(\mathrm{Cx})$ alone or in combination in absence or present of anhydrous sodium sulphate (SS), can improve the performance of local laying hens in their second laying cycle (100-112 weeks). One hundred and ninety two aged Golden Montazah layer hens that reached 100 weeks of age were chosen and distributed randomly into $8^{\text {th }}$ experimental groups. Each group contained 24 hens divided into 3 replicates of 8 hens each. The $1^{\text {st }}$ group fed control diet, the groups from the $2^{\text {nd }}$ to $8^{\text {th }}$ fed control diet supplemented with Thr, Cx, Cx+Thr, SS, SS+Thr, SS+Cx, or SS+Thr+Cx respectively. Egg production performance, egg quality, plasma protein respiration rate and body temperature were estimated.

The results indicated that Thr supplementation improved significantly egg production percent, egg mass and increased significantly feed intake. Feed conversion ratio improved during the first month by supplemented control diet with Thr, and Cx. Moreover plasma globulins and heat tolerance during summer season improved by $\mathrm{Thr}$ supplementation. Combination of $\mathrm{Thr}$ and $\mathrm{Cx}$ supplementation led to attain more improvement in egg production performance. Compared to the control diet, combination of Thr and Cx supplementation increased egg mass per hen by $25.18 \%$. However, no improvement was detected in egg production performance of aged Golden Montazah during summer season due to SS supplementation the control diet.

The results proved the hypothesis that egg production performance of aged Golden Montazah hens improved by threonine and/or canthaxanthin supplementation.
\end{abstract}

Key words: aged hens, threonine, canthaxanthin and sodium sulphate. 


\section{INTRODUCTION}

Natural molting occurs at the end of summer season when day length decreased with the ending of the first laying cycle (Moore et al., 2004). Procedures for improving local aged hens performance during the second laying cycle were conducted for many reasons. Firstly, the long growing period for local chickens that extended from day- one up to 23 weeks of age (age at sexual maturity) (Youssef, et al., 2014). Prolonged rearing period incur producers a lot of money for feeding their pullets especially with increasing poultry ration cost. Secondly, high mortality rate during growing pullets plus increasing vaccines as well as drugs costs also may increase the total expenses. Therefore, it may be more economic to exploit aged chickens and recover egg production performance during the second laying cycle.

Sodium sulphate (SS) may conserve sulfur amino acids through synthesis taurine and condrutine sulphate directly from SS hence preventing sulfur amino acids from degradation (Youssef, 2002). Moreover, SS able to maintain dietary electrolyte balance on optimal limit in broiler diets (Jarule et al., 2009) when sodium chloride partly replaced by SS in layer diets after $43 \mathrm{wks}$ of age production performance and egg shell measurements improved (Wang et al., 2020). Supplementing SS was safety for laying hens with positively effect on egg production performance and shell quality (Wei 2015). Ali et al (2012) indicated that SS increased the activity of hydrophobic antioxidants and protect it from attachment with free radical throughout its circulation in blood fluid.

Threonine (Thr) contain hydroxyl group that make it polar amino acid and it is essential amino acid for poultry (Shirisha et al., 2018). Chicken requirements from glycine can partially replaced by additional $\mathrm{Thr}$ where glycine syntheses from $\mathrm{Thr}$ but the reverse pathway did not complete (Kidd and Kerr 1996). Azzam et al., (2011b) suggested that Thr affect maintenance and function of intestinal tract. Moreover, Thr was involved in amylase enzyme synthesis (Block and Weiss 1966). Threonine dietary levels affected laying rate, feed intake, feed conversion and egg mass
(Schmidt, et al., 2011). Threonine improves poultry tolerance under high ambient temperatures (Shirisha et al., 2018) where it needed more than NRC (1994) requirements under heat stress conditions (Kidd, 2000). Azzam et al. (2012) found that $\mathrm{Thr}$ supplementation improved hen performance they added that threonine may possess antioxidant function under hot climate. Lie et al (2016) found that hens fed $0.67 \%$ L-Thr resulted in the highest total superoxide dismutases and total antioxidative capacity levels in the liver. (Shils, et al. 2006) explained that L-Thr may have an active effect on antioxidant defense systems, and it acts as one of the amino acids that carry a small fraction of copper blood.

Canthaxanthin $(\mathrm{Cx})$ is lipid-soluble carotenoids act as an antioxidant where it improves antioxidant status and laying performance of breeders hens (Zhang et al., 2011). Moreover, $\mathrm{Cx}$ significantly improved feed conversion, average egg weight and laying rate in aged laying hens (Damazia et al., 2018). Umar Faruk et al. (2018) reported that $\mathrm{Cx}$ possess antioxidant effect, enhanced immune responses, raise egg mass, so improved flock productivity. Ali, et al. (2018) reported that $\mathrm{Cx}$ with or without SS was able to improve egg production performance post-peak period. They also found that addition of sulphate to laying hen diets increased the utilization of $\mathrm{Cx}$ and improved egg production performance post-peak period. Therefore, the current experiment aimed to investigate the effect of supplementing cornsoybean meal diet with sodium sulphate, threonine and/or canthaxanthin on egg production performance during the second laying cycle.

\section{MATERIALS AND METHODS}

\section{Experimental treatments:}

Total number of 192 aged Golden Montazah layers were distributed randomly into 8 treatments groups, where each group contained 24 hens and each group divided into three replicates with 8 hens per each. To achieve the experimental purpose one inorganic compound (sodium sulphate) and two organic compounds (threonine and canthaxanthin) were 
supplemented to experimental basal diet. Anhydrous Sodium Sulphate was supplied by the Egyptian Salt and Mineral Company. Canthaxanthin was provided by BASF Germany. Single cage layers were used for hosing each hen individually where each replicate sequentially housed in 8 cages.

A corn-soybean mash meal as a basal experimental layer diet was formulated (Table, 1) to satisfy nutrient requirements (isonitrogenous and iso-caloric) of local laying hens (15\% CP ; $2700 \mathrm{kcal} \mathrm{ME} / \mathrm{kg}$ diet) according to the Agriculture Ministry Decree No 1498 (1996) issued by Egyptian Ministry of Agriculture. The first treatment group fed control basal diet. The $2^{\text {nd }}$ group fed basal diet supplemented with $0.20 \% \mathrm{Thr}$ and the 3rd group fed basal diet supplemented with $3 \mathrm{ppm}$ canthanthin ( $\mathrm{Cx}$; equal $30 \mathrm{ppm}$ commercial canthanthin). Group 4 fed control diet supplemented with mixture of $0.2 \%$ Thr of and $30 \mathrm{ppm} \mathrm{Cx}$ together. Treatments group from 5 to 8 fed the previous diets (control, $2^{\text {nd }}, 3^{\text {rd }}$, and $4^{\text {th }}$ ) with adding $0.50 \%$ SS to form $5^{\text {th }}, 6^{\text {th }}, 7^{\text {th }}$ and $8^{\text {th }}$ treatment diets.

\section{Management and performance parameters:}

Day light was completed using additional morning artificial light before sunrise to reach 16 hours continuous light. Clean water was available continuously without supplemented vitamins source. Temperature and relative humidity inside the layer house recorded daily at $12 \mathrm{pm}$. Selected hens kept for three months during period extended from 100 to 112 wks of age and fed previous diets under the same conditions. Feed provided at the beginning of each week where the remaining diets weighed at weekend and feed intake was calculated.

Daily produced eggs were counted and weighed separately for each replicate to obtain egg mass. Egg production percent (EP percent) calculated by dividing egg number on number of alive hens. Egg mass per hen per day $(\mathrm{EM} / \mathrm{H})$ was calculated by dividing total egg mass of each replicate on number of alive hens. Feed conversion ratio was calculated by dividing feed intake on egg mass (gm feed per gm egg mass).
At the end of the experiment, 7 fresh eggs from each replicate were weighed individually where length and breadth of each egg were measured. Each egg was broken to evaluate egg component percent (yolk, shell and albumen that calculated by subtraction) albumen, yolk height and yolk width were measured. Shells were left to dry for three days in room temperature then weighed and shell thickens measured. Shape index was calculated by divided width on length but yolk index calculated by dividing yolk height by yolk width. Hough unit was calculated from Haught (1937) equation.

Two hens were picked up from each replicate firstly, at 6 am (early in the morning) and were picked up secondly, at 12 am (at afternoon). Body temperature for each hen measured by inserting digital thermometer into rectal for 2 $\mathrm{cm}$ depth (end of the mercury limit). Respiration rate was measured by counting moving of breast up and down for 1 minute.

One blood sample was withdrawn individually from one hen per replicate in test tube contained EDTA. To obtain plasma blood samples centrifuged at $3500 \mathrm{rpm}$ for 15 minutes. Plasma were collected to measure total plasma protein and albumin using colorimetric kits produced by bio-diagnostic. Globulin calculated by subtract albumin from total protein. Albumin/globulin ratio (alb/glo) calculated by dividing albumin values upon globulin values.

\section{Statistical analysis:}

Univariate procedure branch of General linear model that pulled down from analyze menu in statistical software package (SPSS, 2007) was employed to conduct two-way ANOVA along with the following statistical model:

Yijk $=\mu+S_{i}+T_{j}+C_{k}+(S \times T) i j+(S \times C) i k+$ $(\mathrm{T} \times \mathrm{C}) \mathrm{jk}+(\mathrm{S} \times \mathrm{T} \times \mathrm{C}) \mathrm{ijk}+\mathrm{eijk}$

Where,

Yijk = dependent observation.

$\mu=$ overall mean.

$S_{i}=$ effect of $S S(i=1$ and 2$)$. (Main effect)

$\mathrm{T}_{\mathrm{j}}=$ effect of $\operatorname{Thr}(\mathrm{j}=1$ and 2$)$. (Main effect)

$\mathrm{C}_{\mathrm{k}}=$ effect of $\mathrm{Cx}(\mathrm{k}=1$ and 2). (Main effect)

$(\mathrm{S} \times \mathrm{T}) \mathrm{ij}=$ effect of interaction between $\mathrm{SS}$ and Thr. 
$(\mathrm{S} \times \mathrm{C}) \mathrm{ik}=$ effect of interaction between $\mathrm{SS}$ and $\mathrm{Cx}$.

$(\mathrm{T} \times \mathrm{C}) \mathrm{jk}=$ effect of interaction between $\mathrm{Thr}$ and $\mathrm{Cx}$.

$(\mathrm{S} \times \mathrm{T} \times \mathrm{C})=$ effect of interaction among SS, Thr and $\mathrm{CX}$.

eijk $=$ the residual effect.

According to (Duncan, 1955), compare means procedure of (SPSS, 2007) was used to compare means at F-test $(\mathrm{P} \leq 0.05)$.

\section{RESULTS AND DISSCUSION}

\section{1- Production performance:}

Data presented in Table (2) illustrate main effect of SS, Thr and Cx on egg production performance during second production cycle. Regarding SS supplementation, the results show unexpected manner where, the diet contained SS affected negatively on all egg production parameters especially after the first month of the trial. Compared to the control, addition of $\mathrm{Thr}$ increased EM/H by $22.48 \%$. Ali et al. (2018), indicated that birds may use amino acid as antioxidants. Moreover Grune et al. (1997) reported that amino acid play essential role in antioxidant defenses against free radical attack where protein (the most important fraction in layers diet) degraded to produce amino acids. Supplemented diets with SS caused significant decrease in EP percent and $\mathrm{EM} / \mathrm{H}$ during the $2^{\text {nd }}$ and $3^{\text {rd }}$ months and entire experimental period. Similarly, significant retardation in feed intake and feed conversion ratio were observed where its means increased significantly $(\mathrm{P}<0.05)$ for all months and entire period. The results of SS supplementation clearly disagree with those of Ali et al. (2018) who observed significant improvement in egg number, egg mass and feed conversion when hens aged from 39 to 58 wks feed basal diet supplemented with $0.5 \%$ SS. The current adverse results may be due to protein and sulfur amino acids percent in control basal diet were satisfied layers requirements. Ali et al. (2011) found that SS supplementation improved growth performance of low protein diets and this finding support our postulation where sulfur amino acids satisfied protein requirement during the second laying cycle. Moreover, layers during second cycle reached mature weight and change in body weight unnoticed during the experimental period. Otherwise, trail started at 100 weeks of age and after natural molting occurred and hens coated completely by feathers hence requirements from sulfur amino acids for forming or re-molting feather decreased. Ali et al. (2012) indicated that SS increased the activity of hydrophobic antioxidants and/ or protect it from free radical attach during circulation in the blood.

Regarding Thr effects, data showed significant improvement in EP percent during the $2^{\text {nd }}, 3^{\text {rd }}$ months and entire period. Similarly, EM/H showed significant improvement during all months and entire period however, improvement in feed conversion was significantly during the first month only. On the other hand, feed intake increased significantly for all months and entire period. These results agree with Azzam et al., (2011a) who presented data demonstrated that egg production increased by about $5 \%$ when Thr supplementation increased from 0 to $0.3 \%$. Moreover, the results of $\mathrm{Thr}$ supplementation were in full agreement with Schmidt et al., (2011) who observed significant improvement in laying rate, egg mass and feed conversion during the second laying cycle. Results of Thr explain that clear improvement in second production cycle may be due to many reasons. Firstly, requirements of Thr according to NRC (1994) may be insufficient to satisfy laying hen requirements and increasing it to $130 \%$ above NRC may be needed where, (Kallam, 2016) reported that changes in production systems and environment temperature led to update $\mathrm{Thr}$ requirements in laying hen diets. Secondly, part from Thr may convert to glycine (Kidd and Kerr, 1996). Thirdly, Thr may improve digestion where Li et al., (2016) reported that Thr above NRC limit may increase activities of digestive enzymes, improve antioxidant capacity and increase antibody production.

Threonine has antioxidant activity where Li et al., (2016) reported that Thr above NRC limit increased activities of antioxidant capacity. In hot climates Thr supplementation recorded the highest serum and liver superoxide dismutases 
values and certainly has antioxidant function (Azzam et al., 2012). The current experiment was carried out in hot climate where the house temperature ranged from $35^{\circ} \mathrm{C}$ to $39^{\circ} \mathrm{C}$ through the experimental period.

Inclusion of $\mathrm{Cx}$ into the basal diets caused significant increase in $\mathrm{EP}$ percent and $\mathrm{EM} / \mathrm{H}$ during the $1^{\text {st }}, 3^{\text {rd }}$ months and entire period (Table, 2). Compared to the control diet, addition of $\mathrm{Cx}$ increased $\mathrm{EM} / \mathrm{H}$ by $19.21 \%$. These results agree with those obtained by Ali et al. (2018) who found that addition of $\mathrm{Cx}$ increased egg number by $23.35 \%$. Also, results of this study were in full agreement with Umar Faruk et al., (2018) who reported that Cx can increase numerically EP percent and significantly EM/H. According to Bonilla et al., (2017) effect of $\mathrm{Cx}$ in improving egg production performance clearly appears as hen aged and this is may be due to free radicals increased by increasing hen age under high ambient temperature (Ali et al., 2012) where Cx possess antioxidant activity (Zhang et al., 2011) therefore egg production performance improved in aged hens (Damazia et al., 2018). Feed intake increased significantly when aged layers feed diet supplemented with Cx (Table, $2)$. These results are in full agreement with those of Umar Faruk et al., (2018) who reported that increase in feed intake with $\mathrm{Cx}$ supplementation. Increasing feed intake by $\mathrm{Cx}$ supplementation may be due to increasing $\mathrm{EM} / \mathrm{H}$ that may be need more feed for egg production.

The best values that recorded for all production parameters within treatment groups otherwise interaction (Table, 2 continued) was recorded when Thr was mixed with $\mathrm{Cx}$ especially with absence of SS. Compared to control diet, addition of $\mathrm{Thr}+\mathrm{Cx}$ increased $\mathrm{EM} / \mathrm{H}$ by $25.18 \%$. These results agree with Ali et al. (2018) who found that addition of tyrosine plus $\mathrm{Cx}$ increased egg number by $31.63 \%$ compared to their control. This may be due to each of Thr and $\mathrm{Cx}$ possess more critical roles in antioxidant activities as free radicals increase with increasing age (aging) according to Finkel and Holbrook, (2000). Under high ambient temperature, increasing in free radicals production observed by increasing hens age (Ali et al. 2012) so combination effect between Thr and Cx appeared clear improvement in egg production performance.

\section{2- Egg quality:}

All egg quality parameters did not show significant differences neither between treatment groups nor between main effects except for egg shell weight percent for Thr supplementation (Table, 3 ). This result is in full agreement with Schmidt, et al., (2011) and Nunes et al., (2015) who found significant increase in shell weight percent when Thr supplemented to control diet. Increase in egg shell weight percent may be due to decreasing albumen weight percent with constant of yolk weight percent. Decreasing albumen weight percent agree with the next results of plasma protein fraction that will discuss later. Decreasing albumen weight percent agree with (Agustini et al., 2014) who reported that greatest insert of Thr related with the lowest albumen weight percent.

Yolk weight percent and shell thickness were not influence significantly by $\mathrm{Thr}$ supplementation (Table, 3). This result in a full agreement with Nunes et al., (2015) who reported that dietary Thr did not affect on yolk weight percent and shell thickness. Nevertheless, Thr constitute the highest values of amino acid percentage in yolk protein (48 $\mathrm{mg} / \mathrm{g}$ protein) (Sakanaka et al., 2004). The current results of $\mathrm{Cx}$ disagree with previous results Ali et al. (2018) who found Cx significantly increased shell thickness compared to control diet at late egg production cycle. The difference between this study and previous Ali et al. 2018 may be due to different egg production cycle.

\section{3- Heat tolerance and plasma proteins:}

Ambient temperatures were $29^{\circ} \mathrm{C}, 35^{\circ} \mathrm{C}$ and $39^{\circ} \mathrm{C}$ during $1^{\text {st }}, 2^{\text {nd }}$ and $3^{\text {rd }}$ month of current experiment. On the other hand the relative humidity were $48 \%, 54 \%$ and 52.5 during $1^{\text {st }}$, $2^{\text {nd }}$ and $3^{\text {rd }}$ month. Table (4) showed that a numerical slight decrease in rectal body temperature was observed for hens fed diet supplemented with Thr at early morning or at afternoon. The result of body temperature 
agrees with Trevisi et al. (2015) who reported that rise in body temperature prevented by Thr supplementation they could not explain this finding. This is may be due either to Thr turned over to glycine (Kidd and Kerr 1996) hence, glycine able to decrease body temperature (Miura 2004).

Chickens fed diet supplemented with Thr regardless other components exhibited significant decrease in respiration rate when it recorded in early morning or in afternoon (Table, 4). In contrast feeding layers hen diet supplemented with SS regardless other components caused insignificant increase in respiration rate in afternoon. So the treatments that contained Thr combined with SS (interaction) did not achieve additional significant improvement compared with the control treatment.

Only plasma globulin and $\mathrm{A} / \mathrm{G}$ ratio (Table, 5) showed significant effects by $\mathrm{Thr}$ supplementation but other ingredients did not influence other plasma protein component. Increasing globulin combined with $\mathrm{Thr}$ supplementation may be due to Thr found in globulin in high ratio compared with other protein (Azzam et al., 2011b). Azzam et al., (2011a) found that increasing Thr supplementation from 0 up to $0.3 \%$ caused duplication in total

plasma globulin for hens reared in high ambient temperature.
The data in Table (2) revealed that all parameters of egg production performance were improved during the $2^{\text {nd }}$ and $3^{\text {rd }}$ month of experiment phase when ambient temperature ranged between $35^{\circ} \mathrm{C}$ to $39{ }^{\circ} \mathrm{C}$. More $\mathrm{Thr}$ is required under heat stress conditions (Kidd, 2000). moreover dietary $\mathrm{Thr}$ requirements according (NRC, 1994) were insufficient for layer during summer seasons (Azzam et al., 2011b). On the other hand, Thr concentration in $\gamma$-globulin was very high (Azzam and ElGogary 2015) so $\mathrm{Thr}$ deficiency inhibit antibody activity (Kidd 2000) and in-ovo Thr injection induced more formation of immunoglobulin (Kadam et al., 2008)

\section{CONCLUSION}

In conclusion supplemented threonine and canthaxanthin or its combination revealed clear improvement in egg production performance of Golden Montazah during the second laying cycle when reared under hot summer conditio 
Table (1): Composition and calculated analysis of the control diet.

\begin{tabular}{|l|c|}
\hline Ingredients & $\%$ \\
\hline Yellow corn & 64.70 \\
Soybean meal (46\%) & 20.30 \\
Wheat bran & 4.80 \\
Lime stone & 8.00 \\
Di-calcium phosphate & 1.45 \\
Nacl & 0.30 \\
Vitamin\& Min. Mix* & 0.40 \\
DL- methionine & 0.05 \\
Total & 100 \\
\hline Calculated analysis** & \\
\hline CP\% & 15.06 \\
ME Kcal /kg & 2705.3 \\
Crude fiber\% & 3.15 \\
Crude fat \% & 2.93 \\
Calcium \% & 3.35 \\
Available phosphorus \% & 0.402 \\
Lysine \% & 0.795 \\
Methionine \% & 0.332 \\
Methionine + Cysteine\% & 0.588 \\
Sodium\% & 0.14 \\
\hline
\end{tabular}

* Vitamin and mineral mix contain per 4kg vit A 15000 000, vit $\mathrm{D}_{3} 3300000 \mathrm{IU}$, vit E 80 000mg, Vit K3 4000mg, vit B1 $2200 \mathrm{mg}$, vit B2 12 000mg, vit B6 $5500 \mathrm{mg}$, vit B12 $20 \mathrm{mg}$, pantothenic acid $20000 \mathrm{mg}$, Niacin 40 000mg, Biotin $300 \mathrm{mg}$, Folic acid 1500mg, Choline chloride 1000 gm, Selenium $300 \mathrm{mg}$, Copper $10000 \mathrm{mg}$, Iron $60000 \mathrm{mg}$, Manganese 100 000mg, Zinc 80 000mg, Iodine $2000 \mathrm{mg}$, Cobalt $100 \mathrm{mg}$ and $\mathrm{CaCO}_{3}$ to $3000 \mathrm{~g}$.

**According to Egyptian Feed Composition Tables for Animal and Poultry Feedstuffs (2001) 
Table (2): Effect of sodium sulphate, cxthaxanthin and/or threonine on egg production performance (main effects).

\begin{tabular}{|c|c|c|c|c|c|c|c|c|c|c|c|c|c|}
\hline \multirow[t]{2}{*}{ Parameters } & \multirow[t]{2}{*}{$\begin{array}{c}\text { Mont } \\
\text { h }\end{array}$} & \multicolumn{4}{|c|}{ SS } & \multicolumn{4}{|c|}{ Thr } & \multicolumn{4}{|c|}{$\mathbf{C x}$} \\
\hline & & $\begin{array}{c}\text { witho } \\
\text { ut }\end{array}$ & with & SE. \pm & $\begin{array}{c}\mathbf{P} \\
\text { value }\end{array}$ & $\begin{array}{c}\text { witho } \\
\text { ut }\end{array}$ & with & SE. \pm & $\begin{array}{c}\mathbf{P} \\
\text { value }\end{array}$ & $\begin{array}{c}\text { witho } \\
\text { ut }\end{array}$ & with & SE. \pm & $\begin{array}{c}\mathbf{P} \\
\text { value }\end{array}$ \\
\hline \multirow{4}{*}{$\begin{array}{l}\text { Egg } \\
\text { production } \\
\text { percent }\end{array}$} & $1^{\text {st }}$ & 42.71 & 46.01 & 1.210 & 0.054 & 43.18 & 45.55 & 1.210 & 0.165 & $40.28^{b}$ & $48.44^{\mathrm{a}}$ & 1.210 & 0.0001 \\
\hline & $2^{\text {nd }}$ & $60.88^{a}$ & $56.60^{\mathrm{b}}$ & 0.983 & 0.002 & $53.30^{\mathrm{b}}$ & $64.18^{\mathrm{a}}$ & 0.983 & 0.001 & 58.22 & 59.26 & 0.983 & 0.454 \\
\hline & $3^{\text {rd }}$ & $58.98^{\mathrm{a}}$ & $48.49^{\mathrm{b}}$ & 0.963 & 0.001 & $49.94^{\mathrm{b}}$ & $57.53^{\mathrm{a}}$ & 0.963 & 0.001 & $52.20^{\mathrm{b}}$ & $55.27^{\mathrm{a}}$ & 0.963 & 0.024 \\
\hline & Overa & $54.19^{\mathrm{a}}$ & $50.37^{\mathrm{b}}$ & 0.655 & 0.001 & $48.81^{\mathrm{b}}$ & $55.75^{\mathrm{a}}$ & 0.655 & 0.001 & $50.23^{\mathrm{b}}$ & $54.33^{\mathrm{a}}$ & 0.655 & 0.001 \\
\hline \multirow{4}{*}{$\begin{array}{l}\text { Average egg } \\
\text { weight (gm) }\end{array}$} & $1^{\text {st }}$ & 54.09 & 54.18 & 0.18 & 0.719 & 54.31 & 53.95 & 0.18 & 0.158 & 54.31 & 53.95 & 0.180 & 0.335 \\
\hline & $2^{\text {nd }}$ & 53.26 & 53.38 & 0.447 & 0.849 & 53.85 & 52.78 & 0.447 & 0.092 & 53.48 & 53.15 & 0.447 & 0.597 \\
\hline & $3^{\text {rd }}$ & 53.49 & 53.19 & 0.136 & 0.09 & 53.49 & 53.19 & 0.136 & 0.117 & 53.39 & 53.29 & 0.136 & 0.621 \\
\hline & Overa & 53.48 & 53.72 & 0.167 & 0.311 & 53.88 & 53.31 & 0.167 & 0.015 & 53.71 & 53.48 & 0.167 & 0.34 \\
\hline \multirow{5}{*}{$\begin{array}{l}\text { Egg mass / } \\
\text { hen / day } \\
(\mathrm{gm})\end{array}$} & $1^{\mathrm{st}}$ & $23.18^{\mathrm{b}}$ & $25.03^{\mathrm{a}}$ & 0.67 & 0.049 & 23.55 & 24.66 & 0.669 & 0.001 & $21.96^{\mathrm{b}}$ & $26.25^{\mathrm{a}}$ & 0.669 & 0.243 \\
\hline & $2^{\text {nd }}$ & $32.45^{\mathrm{a}}$ & $30.17^{\mathrm{b}}$ & 0.591 & 0.006 & $28.69^{b}$ & $33.93^{\mathrm{a}}$ & 0.591 & 0.001 & 31.1 & 31.52 & 0.591 & 0.614 \\
\hline & $3^{\text {rd }}$ & $31.27^{\mathrm{a}}$ & $25.95^{\mathrm{b}}$ & 0.510 & 0.001 & $26.68^{b}$ & $30.54^{\mathrm{a}}$ & 0.510 & 0.001 & $27.75^{\mathrm{b}}$ & $29.47^{\mathrm{a}}$ & 0.510 & 0.018 \\
\hline & Overa & 28.97 & 27.05 & 0.363 & 0.001 & $26.31^{\mathrm{b}}$ & $29.71^{\mathrm{a}}$ & 0.363 & 0.001 & $26.94^{\mathrm{b}}$ & $29.08^{\mathrm{a}}$ & 0.363 & 0.001 \\
\hline & $1^{\text {st }}$ & $105.0^{\mathrm{a}}$ & $103.8^{\mathrm{b}}$ & 0.001 & 0.001 & $103.8^{\mathrm{b}}$ & $105^{\mathrm{a}}$ & 0.001 & 0.001 & $101.3^{\mathrm{b}}$ & $107.5^{\mathrm{a}}$ & 0.001 & 0.001 \\
\hline \multirow{3}{*}{ Feed intake } & $2^{\text {nd }}$ & 107.28 & 106.65 & 0.238 & 0.061 & $\begin{array}{c}104.43 \\
\mathrm{~b}\end{array}$ & $109.5^{\mathrm{a}}$ & 0.238 & 0.001 & $\underset{\mathrm{b}}{106.01}$ & $\underset{\mathrm{a}}{107.92}$ & 0.238 & 0.001 \\
\hline & $3^{\mathrm{rd}}$ & $\underset{\mathrm{a}}{105.41}$ & $\underset{\mathrm{b}}{104.04}$ & 0.119 & 0.001 & $\underset{\mathrm{b}}{101.70}$ & $\underset{\mathrm{a}}{107.74}$ & 0.119 & 0.001 & $\underset{\mathrm{b}}{104.20}$ & $\underset{\mathrm{a}}{105.24}$ & 0.119 & 0.001 \\
\hline & Overa & $\underset{\mathrm{a}}{105.90}$ & $\begin{array}{c}104.81 \\
\mathrm{~b}\end{array}$ & 0.101 & 0.001 & $\underset{\mathrm{b}}{102.46}$ & $\underset{\mathrm{a}}{108.25}$ & 0.101 & 0.001 & $\begin{array}{c}104.65 \\
\mathrm{~b}\end{array}$ & $\underset{\mathrm{a}}{106.05}$ & 0.101 & 0.001 \\
\hline \multirow{4}{*}{$\begin{array}{l}\text { Feed } \\
\text { conversion }\end{array}$} & $1^{\text {st }}$ & $6.08^{\mathrm{a}}$ & $5.47^{\mathrm{b}}$ & 0.196 & 0.028 & $6.31^{\mathrm{a}}$ & $5.24^{\mathrm{b}}$ & 0.196 & 0.001 & 5.73 & 5.83 & 0.196 & 0.719 \\
\hline & $2^{\text {nd }}$ & $3.81^{b}$ & $4.20^{\mathrm{a}}$ & 0.124 & 0.026 & 3.99 & 4.02 & 0.124 & 0.073 & 4.27 & 3.74 & 0.124 & 0.831 \\
\hline & & $3.62^{\mathrm{b}}$ & $4.84^{\mathrm{a}}$ & 0.114 & 0.001 & 4.39 & 4.07 & 0.114 & 0.051 & 4.3 & 4.16 & 0.114 & 0.366 \\
\hline & $\begin{array}{l}\text { Overa } \\
11\end{array}$ & $4.51^{\mathrm{b}}$ & $4.84^{\mathrm{a}}$ & 0.092 & 0.011 & 4.79 & 4.55 & 0.092 & 0.058 & 4.87 & 4.47 & 0.092 & 0.053 \\
\hline
\end{tabular}

SS: Sodium sulphate Thr: Threonine Cx: Canthaxanthin .

a,b: Means in the same row within the same substance with different superscripts are differ significantly along with $\mathrm{P}$ value. 
Table (2): Continued, Effect of sodium sulphate, cxthaxanthin and/or threonine on egg production performance (treatments effect).

\begin{tabular}{|c|c|c|c|c|c|c|c|c|c|c|c|}
\hline Parameters & $\begin{array}{l}\text { Mont } \\
\text { h }\end{array}$ & $\begin{array}{c}\text { Contr } \\
\text { ol }\end{array}$ & Thr & $\mathbf{C x}$ & $\begin{array}{l}\text { Cx } \times \\
\text { Thr }\end{array}$ & SS & $\begin{array}{l}\text { SSx } \\
\text { Thr }\end{array}$ & $\begin{array}{r}\text { SS } \times \\
\text { Cx }\end{array}$ & $\begin{array}{c}\text { SS } \times \\
\text { Thr } \times \\
\text { Cx }\end{array}$ & SE. \pm & $\begin{array}{c}P \\
\text { value }\end{array}$ \\
\hline \multirow{3}{*}{$\begin{array}{l}\text { Egg production } \\
\text { percent }\end{array}$} & $2^{\text {nd }}$ & $53.24^{\mathrm{d}}$ & $65.51^{\mathrm{a}}$ & $59.73^{c}$ & $65.05^{\mathrm{a}}$ & $50.00^{\mathrm{F}}$ & $64.13^{\mathrm{ab}}$ & $50.23^{f}$ & $62.04^{\mathrm{b}}$ & 1.966 & 0.040 \\
\hline & $3^{\text {rd }}$ & $52.55^{\mathrm{cd}}$ & $60.66^{\mathrm{b}}$ & $59.73^{b}$ & $62.97^{\mathrm{a}}$ & $40.27^{\mathrm{f}}$ & $55.32^{\mathrm{c}}$ & $47.22^{\mathrm{d}}$ & $51.16^{\mathrm{cd}}$ & 1.926 & 0.025 \\
\hline & Overa & $46.3^{\mathrm{cd}}$ & $56.87^{\mathrm{b}}$ & $55.03^{\mathrm{b}}$ & $58.57^{\mathrm{a}}$ & $43.98^{\mathrm{d}}$ & $53.78^{b}$ & $49.92^{c}$ & $53.78^{\mathrm{b}}$ & 1.310 & 0.008 \\
\hline \multirow{2}{*}{$\begin{array}{l}\text { Average egg weight } \\
(\mathrm{gm})\end{array}$} & $3^{\text {rd }}$ & 52.88 & 52.79 & 53.67 & 53 & 54.35 & 53.52 & 53.06 & 53.43 & 0.272 & 0.071 \\
\hline & Overa & 53.77 & 53.54 & 53.7 & 52.89 & 54.53 & 52.98 & 53.53 & 53.81 & 0.335 & 0.111 \\
\hline \multirow{3}{*}{$\begin{array}{l}\text { Egg mass / hen / day } \\
(\mathrm{gm})\end{array}$} & $1^{\mathrm{st}}$ & $18.24^{\mathrm{d}}$ & $24.36^{\mathrm{b}}$ & $24.64^{\mathrm{b}}$ & $25.48^{\mathrm{ab}}$ & $22.96^{c}$ & $22.29^{c}$ & $28.37^{\mathrm{a}}$ & $26.50^{\mathrm{ab}}$ & 1.340 & 0.028 \\
\hline & $2^{\text {nd }}$ & $28.45^{\mathrm{c}}$ & $34.95^{\mathrm{a}}$ & $32.12^{\mathrm{b}}$ & $34.3^{\mathrm{a}}$ & $27.43^{\mathrm{cd}}$ & $33.58^{\mathrm{ab}}$ & $26.77^{d}$ & $32.90^{\mathrm{b}}$ & 1.183 & 0.020 \\
\hline & $3^{\text {rd }}$ & $27.76^{\mathrm{c}}$ & $31.89^{\mathrm{b}}$ & $32.00^{\mathrm{ab}}$ & $33.43^{\mathrm{a}}$ & $21.92^{f}$ & $29.44^{\mathrm{bc}}$ & $25.04^{\mathrm{d}}$ & $27.41^{\mathrm{c}}$ & 1.020 & 0.039 \\
\hline Feed intake & Overa & 101.46 & 106.09 & 105.66 & 110.38 & 100.49 & 110.58 & 102.25 & 105.94 & 0.201 & 0.001 \\
\hline \multirow{4}{*}{ Feed conversion } & $1^{\mathrm{st}}$ & 7.26 & 5.51 & 5.63 & 5.93 & 5.52 & 6.97 & 4.50 & 4.90 & 0.393 & 0.006 \\
\hline & $2^{\text {nd }}$ & 4.24 & 3.59 & 3.75 & 3.65 & 4.30 & 3.81 & 4.78 & 3.91 & 0.248 & 0.018 \\
\hline & $3^{\text {rd }}$ & 4.00 & 3.51 & 3.44 & 3.54 & 5.43 & 4.27 & 4.68 & 4.97 & 0.227 & 0.018 \\
\hline & Overa & 5.17 & 4.2 & 4.27 & 4.38 & 5.09 & 5.01 & 4.65 & 4.59 & 0.184 & 0.004 \\
\hline
\end{tabular}

SS: Sodium sulphate Thr: Threonine Cx: Canthaxanthin .

a,b: Means in the same row with different superscripts are significantly different at $(p<0.05)$. 
Table (3): Effect of sodium sulphate, Cxthaxanthin, threonine and its interaction on egg quality.

\begin{tabular}{|c|c|c|c|c|c|c|c|c|c|c|c|c|}
\hline \multicolumn{13}{|c|}{ Main effects } \\
\hline Parameters & & $\mathrm{SS}$ & & & & & & & & & $\mathrm{Cx}$ & \\
\hline & witho & with & SE. \pm & $\mathbf{P}$ & withou & with & SE. \pm & $\mathbf{P}$ & withou & with & SE. \pm & $\mathbf{P}$ \\
\hline Shape index & 77.94 & 77.37 & 1.039 & 0.702 & 76.51 & 78.79 & 1.039 & 0.128 & 77.18 & 78.1 & 1.039 & 0.528 \\
\hline Yolk index & 36.30 & 35.90 & 0.692 & 0.685 & 36.10 & 36.1 & 0.692 & 0.993 & 35.62 & 36.5 & 0.692 & 0.333 \\
\hline Haugh unit & 85.34 & 87.05 & 1.517 & 0.430 & 85.24 & 87.16 & 1.517 & 0.377 & 84.47 & 87.9 & 1.517 & 0.114 \\
\hline Shell thickness & 35.42 & 34.00 & 0.969 & 0.308 & 35.58 & 33.83 & 0.969 & 0.209 & 34.67 & 34.7 & 0.969 & 0.952 \\
\hline Albumen weight $\%$ & 58.14 & 57.77 & 0.579 & 0.653 & 58.51 & 57.4 & 0.579 & 0.182 & 57.60 & 58.3 & 0.579 & 0.392 \\
\hline Yolk weight $\%$ & 30.91 & 31.2 & 0.545 & 0.711 & 31.02 & 31.08 & 0.545 & 0.936 & 31.34 & 30.7 & 0.545 & 0.451 \\
\hline Shell weigh\% & 10.95 & 11.04 & 0.269 & 0.828 & $10.47^{\mathrm{b}}$ & 11.52 & 0.269 & 0.009 & 11.05 & 10.9 & 0.269 & 0.753 \\
\hline & & & & & & Treatme & it effect & & & & & \\
\hline Parameters & Control & Thr & C & & $\begin{array}{l}\text { Cx } \times \\
\text { Thr }\end{array}$ & SS & $\begin{array}{l}\text { SSx } \\
\text { Thr }\end{array}$ & $\mathbf{S S} \times \mathbf{C x}$ & $\begin{array}{r}\text { SS } \times \\
\times \\
\text { C }\end{array}$ & & SE. \pm & P value \\
\hline Shape index & 76.86 & 76.38 & 77 & & 80.95 & 76.21 & 79.28 & 75.42 & 78. & & 2.000 & 0.520 \\
\hline Yolk index & 34.42 & 36.79 & 36 & & 37.14 & 36.51 & 34.76 & 36.63 & 35 . & & 1.384 & 0.462 \\
\hline Haugh unit & 84.79 & 85.03 & 85 & & 86.45 & 82.26 & 85.79 & 88.81 & 91. & & 3.035 & 0.808 \\
\hline Shell thickness & 37.50 & 35.17 & 36 & & 33.00 & 32.33 & 33.67 & 36.5 & 33. & & 1.939 & 0.508 \\
\hline Albumen weight $\%$ & 58.48 & 56.64 & 58 & & 59.20 & 58.41 & 56.88 & 58.91 & 56. & & 1.158 & 0.323 \\
\hline Yolk weight\% & 31.57 & 31.54 & 30 & & 29.94 & 31.48 & 30.79 & 30.45 & 32. & & 1.089 & 0.348 \\
\hline Shell weigh\% & 9.95 & 11.81 & 11 & & 10.87 & 10.11 & 12.33 & 10.64 & 11. & & 0.539 & 0.823 \\
\hline
\end{tabular}

SS: Sodium sulphate Thr: Threonine Cx: Canthaxanthin .

a,b: Means in the same row within the same substance with different superscripts are differ significantly along with $\mathrm{P}$ value. 
Table (4):Effect of sodium sulphate, Cxthaxanthin, threonine and its interaction on body temperature and respiration rate.

\begin{tabular}{|c|c|c|c|c|c|c|c|c|c|c|c|c|c|c|}
\hline \multirow{3}{*}{ Parameters } & \multicolumn{14}{|c|}{ Main effects } \\
\hline & \multicolumn{4}{|c|}{ SS } & \multicolumn{5}{|c|}{ Thr } & \multicolumn{5}{|c|}{$\mathbf{C x}$} \\
\hline & without & with & SE. \pm & P value & without & with & SE. \pm & \multicolumn{2}{|c|}{ P value } & \multicolumn{2}{|c|}{ without } & with & SE. \pm & P value \\
\hline Body temperature 6 & 41.55 & 41.52 & 0.034 & 0.552 & 41.56 & 41.53 & 0.034 & \multicolumn{2}{|c|}{0.932} & \multicolumn{2}{|c|}{41.55} & 41.52 & 0.034 & 0.445 \\
\hline Respiration rate 6 & 27.46 & 27.04 & 0.534 & 0.584 & $28.54^{\mathrm{a}}$ & $25.96^{\mathrm{b}}$ & 0.534 & \multicolumn{2}{|c|}{0.001} & \multicolumn{2}{|c|}{27.29} & 27.21 & 0.534 & 0.913 \\
\hline Body temperature 12 & 41.80 & 41.80 & 0.027 & 0.914 & 41.82 & 41.79 & 0.027 & \multicolumn{2}{|c|}{0.449} & \multicolumn{2}{|c|}{41.80} & 41.80 & 0.027 & 0.955 \\
\hline Respiration rate 12 & 44.58 & 45.54 & 0.544 & 0.144 & $46.88^{\mathrm{a}}$ & $43.25^{\mathrm{b}}$ & 0.544 & \multicolumn{2}{|c|}{0.001} & \multicolumn{2}{|c|}{45.75} & 44.38 & 0.544 & 0.039 \\
\hline & \multicolumn{14}{|c|}{ Treatments effect. } \\
\hline Parameters & control & \multicolumn{2}{|c|}{ Thr } & $\mathbf{C x}$ & $\begin{array}{c}\text { Cx } \times \\
\text { Thr }\end{array}$ & SS & \multicolumn{2}{|c|}{ SS $\times$ Thr } & \multicolumn{2}{|c|}{$\mathbf{S S} \times \mathbf{C x}$} & \multicolumn{2}{|c|}{$\begin{array}{c}\mathbf{S S} \times \mathbf{T h r} \\
\times \mathbf{C x}\end{array}$} & SE. \pm & $P$ value \\
\hline Body temperature 6 & 41.62 & \multicolumn{2}{|c|}{41.58} & 41.47 & 41.53 & 41.52 & \multicolumn{2}{|c|}{41.50} & \multicolumn{2}{|c|}{41.55} & \multicolumn{2}{|c|}{41.52} & 0.069 & 0.552 \\
\hline Respiration rate 6 & $29.33^{\mathrm{a}}$ & \multicolumn{2}{|c|}{$25.67^{\mathrm{c}}$} & $28.17^{\mathrm{ab}}$ & $26.67^{\mathrm{b}}$ & $28.50^{\mathrm{ab}}$ & \multicolumn{2}{|c|}{$25.67^{\mathrm{c}}$} & \multicolumn{2}{|c|}{$28.17^{\mathrm{ab}}$} & \multicolumn{2}{|c|}{$25.83^{\mathrm{c}}$} & 1.067 & 0.0415 \\
\hline Body temperature 12 & 41.83 & \multicolumn{2}{|c|}{41.75} & 41.83 & 41.80 & 41.82 & \multicolumn{2}{|c|}{41.80} & & & & 80 & 0.054 & 0.824 \\
\hline Respiration rate 12 & $49.17^{\mathrm{a}}$ & 41.3 & & $45.17^{b}$ & $42.67^{\mathrm{c}}$ & $47.67^{\mathrm{ab}}$ & 44.8 & & & $50^{\mathrm{b}}$ & & $17^{\mathrm{bc}}$ & 1.087 & 0.034 \\
\hline
\end{tabular}

SS: Sodium sulphate Thr: Threonine Cx: Canthaxanthin .

a,b: Means in the same row within the same substance with different superscripts are differ significantly along with $\mathrm{P}$ value. 
Table(5):Effect of sodium sulphate, Cxthaxanthin, threonine and its interaction on plasma proteins.

\begin{tabular}{|c|c|c|c|c|c|c|c|c|c|c|c|c|}
\hline \multirow{2}{*}{ Parameters } & \multicolumn{4}{|c|}{ SS } & \multicolumn{4}{|c|}{ Thr } & \multicolumn{4}{|c|}{$\mathbf{C x}$} \\
\hline & without & with & SE. & $\mathbf{P}$ & withou & with & SE. \pm & P value & witho & with & SE. & $\mathbf{P}$ \\
\hline Total protein & 6.34 & 6.73 & 0.30 & .391 & 6.48 & 6.59 & 0.309 & .818 & 6.32 & 6.75 & 0.30 & .358 \\
\hline Albumin & 3.54 & 3.88 & 0.15 & .160 & 3.85 & 3.57 & 0.157 & .236 & 3.66 & 3.77 & 0.15 & .645 \\
\hline Globulin & 2.80 & 2.85 & 0.16 & .834 & $2.63^{\mathrm{b}}$ & $3.02^{\mathrm{a}}$ & 0.036 & .137 & 2.66 & 2.98 & 0.16 & .215 \\
\hline $\mathrm{A} / \mathrm{G}$ ratio & 1.29 & 1.39 & 0.05 & .211 & $1.50^{\mathrm{a}}$ & $1.19^{\mathrm{b}}$ & 0.044 & .003 & 1.42 & \multicolumn{2}{|c|}{1.27} & .064 \\
\hline \multirow[b]{2}{*}{ Parameters } & \multicolumn{12}{|c|}{ Treatments effect. } \\
\hline & control & Thr & \multicolumn{2}{|c|}{$\mathbf{C x}$} & $\begin{array}{l}\mathbf{x} \times \\
\mathrm{Thr} \\
\end{array}$ & SS & $\begin{array}{c}\text { SS } \times \\
\text { Thr } \\
\end{array}$ & $\mathrm{SS} \times \mathbf{C x}$ & \multicolumn{2}{|c|}{$\begin{array}{c}\text { SS } \times \text { Thr } \\
\times\end{array}$} & SE. \pm & $P$ value \\
\hline Total protein & 6.24 & 6.82 & \multicolumn{2}{|c|}{6.30} & .99 & 6.11 & 6.77 & 6.64 & \multicolumn{2}{|c|}{7.42} & 0.618 & 0.577 \\
\hline Albumin & 3.85 & 3.81 & \multicolumn{2}{|c|}{3.34} & .17 & 3.89 & 3.87 & 3.56 & \multicolumn{2}{|c|}{4.22} & 0.313 & 0.396 \\
\hline Globulin & 2.39 & 3.02 & \multicolumn{2}{|c|}{2.97} & .82 & 2.22 & 2.89 & 3.09 & \multicolumn{2}{|c|}{3.20} & 0.335 & 0.826 \\
\hline $\mathrm{A} / \mathrm{G}$ ratio & 1.64 & 1.28 & \multicolumn{2}{|c|}{1.13} & .13 & 1.76 & 1.34 & 1.16 & \multicolumn{2}{|c|}{1.32} & 0.104 & 0.475 \\
\hline
\end{tabular}

SS: Sodium sulphate Thr: Threonine Cx: Canthaxanthin .

a,b: a,b: Means in the same row within the same substance with different superscripts are differ significantly along with $\mathrm{P}$ value. 
aged hens, threonine, canthaxanthin and sodium sulphate.

REFERENCES

Agriculture Ministry Decree 1498 1996. The standard properties for ingredients, feed additives and feed manufactured for animal and poultry. EL Wakaee EL-Masria, No. 192 (1997) P 95 Amirria Press Cairo, Egypt.

Agustini, M. A. B.; Nunes, R. V.; Vilela, C. G.; Takahashi, S. E.; Vilela, V. O.; Bueno, R. S.; and Polese, C. 2014. Nutritional levels of digestible threonine in brown-egg laying hens from 75 to 90 weeks of age. Semina: Ciências Agrárias, 35: 3449-3456.

Ali M. N. ; M.S. Hassan ; Kh. M. Attia; M. H.El-Deep ;F.A. Abd El-Ghany ; and Nasra B. Awadein. 2018. Effect of tyrosine, tryptophan and canthanthin either alone or in combination on productive performance of Egyptian developed laying hens in post-peak egg production period, in presence or absence of sodium sulphate. Egyptian Poultry Science Journal, 38: 981-998.

Ali, M. N.; Hassan, M. S.; Abd El-Ghany, F. A.; and Awadein, N. B. 2012. Using natural antioxidants with or without sulphate to improve productive and reproductive performance of two local strains at late egg production period. International Journal of Poultry Science, 11: 269-282.

Ali, M. N.; Moustafa, K. E. ; Shabaan, M.; Radwan, A. M.; and Sayed, M. A. 2011. Effect of using cuminum cyminum L., Citric Acid and sodium sulphate for improving the utilization of low protein low energy broiler diets. Int J Poult Sci, 10: 514-522.

Azzam, M. M. M.; and El-Gogary, M. R. 2015. Effects of dietary threonine levels and stocking density on the performance, metabolic status and immunity of broiler chickens. Asian Journal of Animal and Veterinary Advances, 10: 215-225.

Azzam, M. M. M.; Dong, X. Y.; Xie, P.; and Zou, X. T. 2012. Influence of $\mathrm{L}$-threonine supplementation on goblet cell numbers, histological structure and antioxidant enzyme activities of laying hens reared in a hot and humid climate. British Poultry Science, 53: 640-645.

Azzam, M. M. M.; Dong, X. Y.; Xie, P.; Wang, C.; and Zou, X. T. 2011a. The effect of supplemental L-threonine on laying performance, serum free amino acids, and immune function of laying hens under hightemperature and high-humidity environmental climates. Journal of Applied Poultry Research, 20: 361-370.

Azzam, M. M. M.; Zou, X. T.; Dong, X. Y.; and Xie, P. 2011b. Effect of supplemental Lthreonine on mucin 2 gene expression and intestine mucosal immune and digestive enzymes activities of laying hens in environments with high temperature and humidity. Poultry Science, 90: 2251-2256.

Block, R.J.; and Weiss, D.B. 1966. The Amino Acid Composition of Proteins and Foods, Charles C. Thomas, Springfield, IL. 149-295.

Bonilla, C. E. V.; Rosa, A. P.; Londero, A.; Giacomini, C. B. S.; Orso, C.; Fernandes, M. O.; Paixão, S. J.; and Bonamigo, D. V. 2017. Effect of broiler breeders fed with corn or sorghum diet and canthaxanthin supplementation on production and reproductive performance. Poultry Science. 96: 1725-1734.

Damaziak, K.; Marzec, A.; Riedel, J.; Szeliga, J.; Koczywas, E.; Cisneros, F.; Michalczuk, M.; Lukasiewicz, M.; Gozdowski, D.; Siennicka, A.; Kowalska, H.; Niemiec, J.; and Lenart A. 2018. Effect of dietary canthaxanthin and iodine on the production performance and egg quality of laying hens. Poultry Science, 97: 4008-4019.

Duncan, D. B., 1955. Multiple range and multiple F tests. Biomet. 11: 1-42.

Egyptian Feed Composition Tables for Animal and Poultry Feedstuffs. 2001. Technical bulletin No. 1, central lab. for feed and food, Ministry of Agric., Egypt.

Finkel, T.; and Holbrook, N. J. 2000. Oxidants, oxidative stress and the biology of ageing. Nature 408:239-247 
Grune, T., T. Reinheckel and K.J.A. Davies, 1997. Degradation of oxidized proteins in mammalian cells. FASEB J., 11: 526-534.

Haught, R. P. 1937. Haugh units for measuring egg quality. Poult. Magazine. 43:552-573.

Jarulè, V.; Gružauskas, R.; RacevičiutèStupelienè, A.; Šašytè, V.; Semaškaitė, A.; Tèvelis, V.; Švirmickas, G. J. ; and Švirmickienė, V. 2009. Influence of sodium bicarbonate and sodium sulphate on electrolyte balance and productivity in broiler chickens. Veterinarija Ir Zootechnika, 47: 3-9.

Kadam, M. M.; Bhanja, S. K.; Mandal, A. B.; Thakur, R.; Vasan, P.; Bhattacharyya, A.; and Tyagi, J. S. 2008. Effect of in ovo threonine supplementation on early growth, immunological responses and digestive enzyme activities in broiler chickens. British Poultry Science, 49: 736-741.

Kallam, N. K. 2016. Effect of supplementation of crystalline lysine and threonine on performance of white leghorn layers for cornsoy diet. $\mathrm{PhD}$ Thesis. College of Veterinary Vcience, Telangana State University for Veterinary Animal and Fishery Sciences.

Kidd, M. T. 2000. Nutritional considerations concerning threonine in broilers 1,2 . World's Poultry Science Journal. 56:139-151.

Kidd, M. T.; and Kerr, B. J. 1996. L-threonine for poultry: A review. Journal of Applied Poultry Research, 5: 358-367.

Li, J. M.; Zhang, X. Y.; Yuan, C.; Miao, L. P.; Yan, H. X.; Dong, X. Y.; Lu, J. J.; and Zou, X. T. 2016. Effects of dietary L-threonine levels on antioxidant capacity, digestive enzyme activities, and antibody production of Xinyang green-shell laying hens. Journal of Applied Poultry Research, 25: 422-427.

Miura, H.; Iwasaki, K.; and T. Suzuki, 2004. "Glycine-enriched vegetable compound feed for a layer chicken." U.S. Patent Application No. 10:228-448.

Moore, R. W.; Park, S. Y.; Kubena, L. F.; Byrd, J. A.; McReynolds, J. L.; Burnham, M. R.; Hume, M. E.; Birkhold, S. G.;
Nisbet D. J.; and Ricke, S. C. 2004. Comparison of zinc acetate and propionate addition on gastrointestinal tract fermentation and susceptibility of laying hens to Salmonella enteritidis during forced molt. Poultry science, 83: 1276-1286.

NRC, National Research Council. 1994. Nutrient Requirements of Poultry. 9th revised edition. National Academy Press. Washington, D.C., USA.

Nunes, R. V.; Agustini, M. A. B.; Takahashi, S. E.; Murakami, A. E.; De Souza, C.; Schneiders, S. E.; and Polese, C. 2015. Nutritional requirement of digestible threonine for brown-egg laying hens from 50 to 66 weeks of age. Semina: Ciências Agrárias, 36: 3877-3866.

Sakanaka, S.; Tachibana, Y.; Ishihara, N.; and Juneja, L. R. 2004. Antioxidant activity of egg-yolk protein hydrolysates in a linoleic acid oxidation system. Food Chemistry, 86: 99-103.

Schmidt, M.; Gomes, P. C.; Rostagno, H. S.; Albino, L. F. T.; Nunes, C. G. V.; and Nunes, R. V. 2011. Nutritional levels of digestible threonine for white-egg laying hens in the second cycle of production. Revista Brasileira de Zootecnia, 40: 148-153.

Shils, M. E., M. Shike, A. Ross, C. B. Caballero, and R. J. Cousins. 2006. Modern Nutrition in Health and Disease. Tenth edition. Modern Nutrition in Health and Disease. Lippincott Williams \& Wilkins.

Shirisha, R.; Umesh, B. U.; and Prashanth, K. 2018. Effect of L-Threonine supplementation on broiler chicken: A review. J. Pharm. Innov, 7: 490-493.

SPSS., 2007. SPSS Users Guide Statistics. Version 16. Copyright SPSS Inc., USA.

Trevisi, P.; Corrent, E.; Mazzoni, M.; Messori, S.; Priori, D.; Gherpelli, Y.; Simongiovanni A.; and Bosi, P. 2015. Effect of added dietary threonine on growth performance, health, immunity and gastrointestinal function of weaning pigs with 
aged hens, threonine, canthaxanthin and sodium sulphate.

differing genetic susceptibility to E scherichia coli infection and challenged with E. coli K88ac. Journal of Animal Physiology and Animal Nutrition, 99: 511-520.

Umar Faruk, M.; Roos, F. F.; and CisnerosGonzalez, F. 2018. A meta-analysis on the effect of canthaxanthin on egg production in brown egg layers. Poultry Science, 97: 84-87.

Wang, J.; Zhang, H. J.; Wu, S. G.; Qi, G. H.; and $\mathrm{Xu}$, L. 2020. Dietary chloride levels affect performance and eggshell quality of laying hens by substitution of sodium sulfate for sodium chloride. Poultry Science, 99: 966973.

Wei, S.M. 2015. Study on the Effectiveness, Tolerance of Sodium Sulfate in Laying Hens. MSc. thesis. Chinese Academy of Agricultural Sciences, Beijing, China.
Youssef, S. F. 2002. Physiological, productive and reproductive studies on the effects of supplemented basal diet with organic and inorganic sulfur on chickens. PhD Thesis. Cairo University.

Youssef, S. F.; Yassein, D. M.; El-Bahy, N. M.; and Faddle, A. A. 2014. A comparative studies among golden montazah, el-salam and fayoumi chickens. 1-response to acute heat stress as early heat conditioning procedure. Egypt. Poult. Sci, 34: 1075-1097.

Zhang, W.; Zhang, K. Y.; Ding, X. M.; Bai, S. P.; Hernandez, J. M.; Yao, B.; and Zhu, Q. 2011. Influence of canthaxanthin on broiler breeder reproduction, chick quality, and performance. Poultry Science, 90: 1516-1522. 


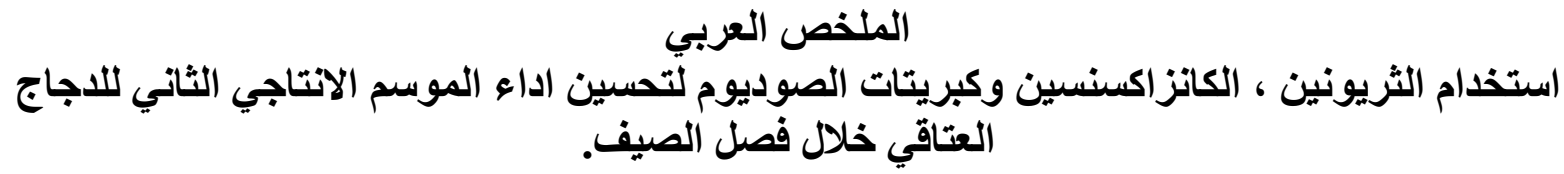

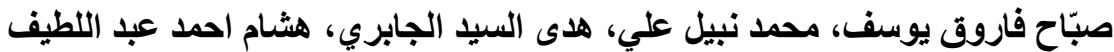

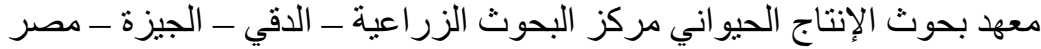

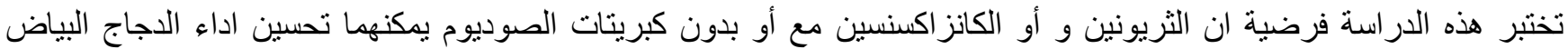

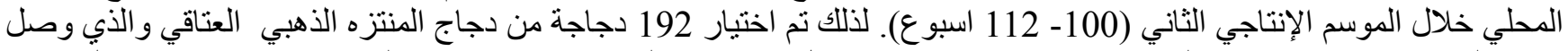

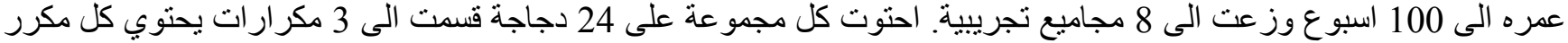

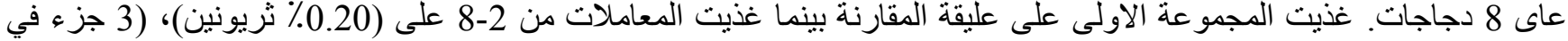

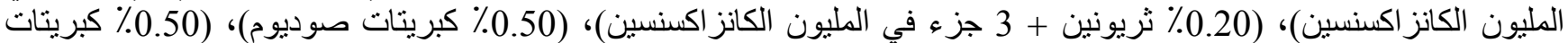

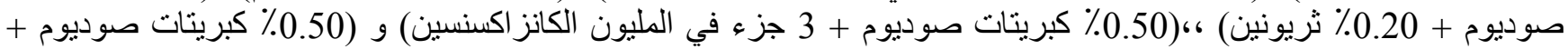

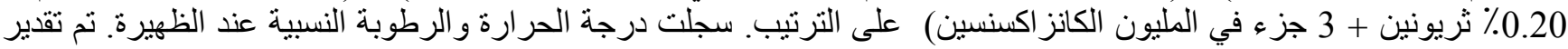

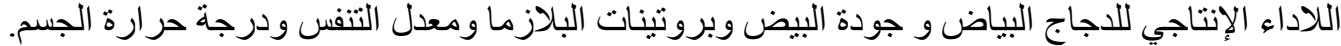

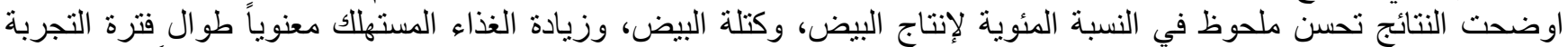

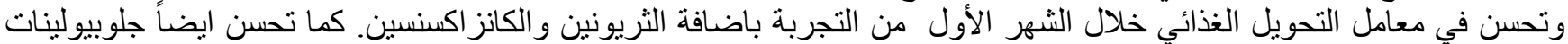

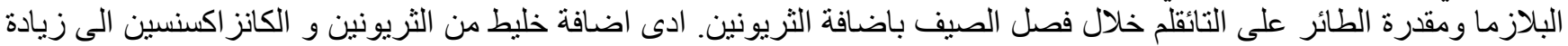

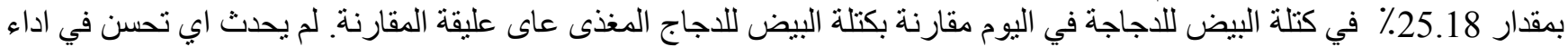

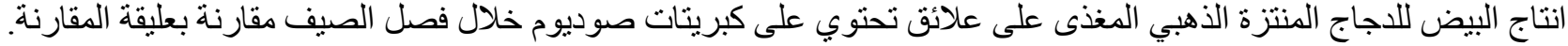

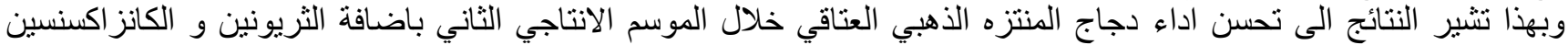

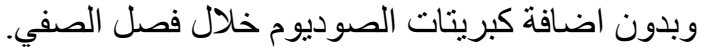

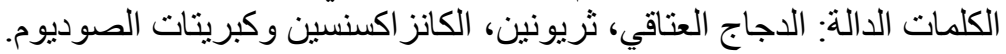

